Review

\title{
Community-Based Healthcare for Migrants and Refugees: A Scoping Literature Review of Best Practices
}

\author{
Elena Riza ${ }^{1, *}$, Shona Kalkman ${ }^{2}$, Alexandra Coritsidis ${ }^{3}$, Sotirios Koubardas ${ }^{1}$, Sofia Vassiliu ${ }^{1}$, \\ Despoina Lazarou ${ }^{4}$, Panagiota Karnaki ${ }^{5}$, Dina Zota ${ }^{5}$, Maria Kantzanou ${ }^{1}$, \\ Theodora Psaltopoulou ${ }^{1}$ and Athena Linos ${ }^{1,5}$ \\ 1 Department of Hygiene, Epidemiology and Medical Statistics, Medical School, National and Kapodistrian \\ University of Athens, 11527 Athens, Greece; koubardas@gmail.com (S.K.); sofia_vassiliu@hotmail.com (S.V.); \\ maria.kantzanou@gmail.com (M.K.); tpsaltop@hotmail.com (T.P.); a.linos@prolepsis.gr (A.L.) \\ 2 Julius Center for Health Sciences and Primary Care, University Medical Center Utrecht, Utrecht University, \\ 3584 CG Utrecht, The Netherlands; shonakalkman@gmail.com \\ 3 Renaissance School of Medicine, Stony Brook University, Stony Brook, NY 11794-8434, USA; \\ Alexandra.Coritsidis@stonybrookmedicine.edu \\ 4 Institute of Human Sciences, Wadham College, University of Oxford, Oxford OX1 3PN, UK; \\ despoina.lazarou@wadham.ox.ac.uk \\ 5 Prolepsis Institute for Preventive Medicine and Environmental and Occupational Health, 15121 Marousi, \\ Greece; p.karnaki@prolepsis.gr (P.K.); d.zota@prolepsis.gr (D.Z.) \\ * Correspondence: eriza@med.uoa.gr; Tel.: +30-210-746-2101
}

Received: 21 February 2020; Accepted: 23 April 2020; Published: 28 April 2020

\begin{abstract}
Background: Strengthening community-based healthcare is a valuable strategy to reduce health inequalities and improve the integration of migrants and refugees into local communities in the European Union. However, little is known about how to effectively develop and run community-based healthcare models for migrants and refugees. Aiming at identifying the most-promising best practices, we performed a scoping review of the international academic literature into effective community-based healthcare models and interventions for migrants and refugees as part of the Mig-HealthCare project. Methods: A systematic search in PubMed, EMBASE, and Scopus databases was conducted in March 2018 following the PRISMA methodology. Data extraction from eligible publications included information on general study characteristics, a brief description of the intervention/model, and reported outcomes in terms of effectiveness and challenges. Subsequently, we critically assessed the available evidence per type of healthcare service according to specific criteria to establish a shortlist of the most promising best practices. Results: In total, 118 academic publications were critically reviewed and categorized in the thematic areas of mental health $(n=53)$, general health services $(n=36)$, noncommunicable diseases $(n=13)$, primary healthcare $(n=9)$, and women's maternal and child health $(n=7)$. Conclusion: A set of 15 of the most-promising best practices and tools in community-based healthcare for migrants and refugees were identified that include several intervention approaches per thematic category. The elements of good communication, the linguistic barriers and the cultural differences, played crucial roles in the effective application of the interventions. The close collaboration of the various stakeholders, the local communities, the migrant/refugee communities, and the partnerships is a key element in the successful implementation of primary healthcare provision.
\end{abstract}

Keywords: scoping review; migrants; refugees best practices; community-based healthcare 


\section{Introduction}

In recent years, over 2,000,000 migrants and refugees have fled civil unrest and socioeconomic instability and come to Europe since 2014 in search of a better and safer future [1]. A large portion of these individuals have come from the Middle East, fleeing conflicts such as the Syrian Civil War. Migrants and refugees worldwide often encounter substantial barriers to healthcare in their new home countries [2]. The World Health Organization in the 2018 "Report on the health of refugees and migrants in the European Union" [3] indicates that there are significant limitations to the accessibility and delivery of proper healthcare, as well as to the degree of effective communication. These limitations are mainly caused by differences in language, lack of knowledge regarding available services, limited participation in the economy, the healthcare system operability in each country, and the varying cultural attitudes and beliefs. As such, migrant and refugee populations are at higher risks of poverty and social exclusion. These barriers lead to inequitable access to healthcare, which is described as a fundamental human right. To reduce and prevent health inequalities among migrants and refugees in Europe, local healthcare systems will need to adapt to the specific needs of this population. There is evidence that integration into existing healthcare systems is promoted through tailored services at the level of local communities [4]. However, little is known on how to effectively develop and run community-based healthcare models for migrants and refugees.

In an effort to provide evidence-based information and practical guidance to the health professionals working at the primary healthcare level primarily in the EU Member States, the Mig-HealthCare project was launched in May 2017 (www.mighealthcare.eu) [5], partially funded by the European Commission Consumer, Health, Agriculture and Food Executive Agency (CHAFEA). The project's aim is to produce a roadmap to effective community-based healthcare models in order to improve physical and mental healthcare services, to support the inclusion and participation of migrants and refugees in European communities, and to reduce health inequalities.

As part of the activities planned within this project, a systematic search in scientific databases was conducted with the objective to identify effective community-based healthcare models and interventions for migrants and refugees that could be used as best practices.

We performed a comprehensive review based on a search of the international, peer-reviewed literature to identify requirements, prerequisites, and concrete steps to design and implement community-based healthcare models serving migrants and refugees. The first step was to map the different models that are reported worldwide in the academic literature, along with their characteristics, core elements, and reported outcomes. Secondly, we critically analyzed the effectiveness of the models and interventions by applying prespecified criteria. Thirdly, based on our critical analysis and criteria evaluation, a shortlist of potential best practices and tools was created. Our findings are intended to provide policy-makers and health service providers working with migrant and refugee populations the concrete steps to successfully develop strategies to address and prevent health inequalities and foster integration at the level of local communities in Europe.

One of the immediate challenges of this task was the controversy surrounding the terms community-based healthcare and community health. The terms are often used in different contexts, and different countries may use the terms in different ways. Nevertheless, we believe meaningful results can be obtained from a review of publications explicitly addressing community-based models and interventions. For the purpose of this review, we use a broad conception of community as "a group of inhabitants living in a somewhat localized area under the same general regulations and having common norms, values, and organizations" [6]. Community health refers to the health status of a defined group of people and the actions and conditions, both private and public (governmental), to promote, protect, and preserve their health [7]. Migrant and refugees are terms that are often used interchangeably, but they are defined by the United Nations High Commission for Refugees (UNHCR) as follows [8]: Migrants: "While there is no formal legal definition of an international migrant, most experts agree that an international migrant is someone who changes his or her country of usual residence, irrespective of the reason for migration or legal status. Generally, a distinction is 
made between short-term or temporary migration, covering movements with a duration between three and 12 months, and long-term or permanent migration, referring to a change of country of residence for a duration of one year or more".

Refugees are "persons who are outside their country of origin for reasons of feared persecution, conflict, generalized violence, or other circumstances that have seriously disturbed public order and, as a result, require international protection. The refugee definition can be found in the 1951 Convention and regional refugee instruments, as well as UNHCR's Statute".

\section{Materials and Methods}

\subsection{Search Strategy and Selection}

A literature search was performed for articles published in the English language following the PRISMA statement [9] in March 2018 in the databases: PubMed, EMBASE, and Scopus. Keywords and terms used were: "migrant", "immigrant", "refugee", "asylum-seeker", "healthcare", "community-based", and "model", combined with an "AND" and/or an "OR".

No limits for publication dates were set; however, we divided our search in pre and post-2012 publication dates in an effort to effectively capture data on the recent migrant/refugee influx into Europe after 2011 following the civil unrest in countries of the Middle East and Africa, as our effort is of particular relevance to the present migrant/refugee crisis in Europe. Publications dated before 2012 have been published mostly with respect to migrant/refugee populations in countries outside Europe, such as the United States and Australia, in years predating the current European influx of migrants and refugees from Africa and the Middle East.

\section{Inclusion and Exclusion Criteria}

Publications were eligible for review if they provided a comprehensive description of community-based models for healthcare delivery to migrant/refugee/asylum-seeking populations or other relevant minorities, as the provision of healthcare in some of these groups depends on legal status. In our selection of relevant publications, we employed a fairly broad concept of healthcare to deliberately cover different types of healthcare services and migrant/refugee population subgroups, such as adolescents, mothers, chronic patients, and migrants. This was done in order to produce a shortlist of potential best practices and tools covering the whole range of community-based health services so as to provide a broad base of information useful to policy-makers, researchers, and funders who work in this field. Eligibility was not restricted to models and interventions for specific groups of migrants and refugees. We included all ages, ethnicities, refugees, and migrants of any status. Explicit mentioning of the terms "vulnerability" or "vulnerable" was not required for inclusion, as we considered all migrants and refugees inherently vulnerable. All publications that proposed, discussed, or formally assessed a community-based model or intervention were included in the systematic collection and analysis. We excluded publications that only reported on health needs, barriers, and challenges to healthcare access among migrants and refugees without containing the element of specific practices and tools. Papers reporting on methods for participatory community-based health research, healthcare models strictly for rural or low-resource areas, and papers on models to engage migrants in clinical research were also excluded. Abstracts and conference proceedings were excluded from the formal analysis, as an in-depth critical review was not possible to the same extent as it was for full-text publications.

\subsection{Data Extraction}

For all articles included in the final analysis, data was extracted on the following variables: (1) full citation, (2) year of publication, (3) type of study/paper, (4) country of implementation, (4) target population, (5) type of care/health needs, (6) model/intervention (keywords), (7) basic characteristics of the model/intervention, (8) best practices, (9) lessons learned, and (10) challenges and limitations. 
For the critical appraisal, we also extracted data on: (11) mode of evaluation (according to study design); (12) duration of follow-up (evaluation); (13) study sample (if applicable); and (14) theoretical underpinnings (e.g., for interventions based on behavioral or other models related to perceptions, attitudes, and barriers to change habits). All 3054 identified articles were screened by three independent reviewers, and the results were jointly discussed.

To facilitate the analysis, the publications were grouped by indication/disease area through an iterative process and, subsequently, categorized as models or interventions for health promotion/education, prevention, or disease management.

\subsection{Critical Assessment for Best Practices}

We define "best practices" as interventions for which there is evidence to substantiate (at least some form of) effectiveness. To assess effectiveness, interventions described per category were evaluated based on the following criteria: study design; sample size; duration of follow-up; whether the study population was of Middle Eastern/North African descent (as this relates strongly to the increased influx of migrants/refugees into Europe following the civil unrest in several countries in the area, such as Syria, Iraq, Libya, and Lebanon); reported specific outcomes/advocate evidence-based approach; presence of theoretical underpinnings; and potential for reproducibility. For each of the above-mentioned variables, a marking scheme with subcategories was applied, and the total score was calculated for each practice to assess the level of evidence for the effectiveness of interventions and models for community-based healthcare for migrants and refugees (Table 1). Each study was assessed according to the criteria set in an Excel file, and the total score was computed automatically as the addition of the subscores in each category.

No score threshold was set, as this was a comparative process among the interventions identified in this review. The higher the total score, the more scientifically robust the proposed intervention was indicated. 
Table 1. Evaluation criteria of selected interventions on community-based best practices.

\begin{tabular}{|c|c|c|c|c|c|c|}
\hline Study Design & Sample Size $(n)$ & $\begin{array}{l}\text { Duration of } \\
\text { Follow-Up }\end{array}$ & $\begin{array}{c}\text { Middle Eastern/North } \\
\text { African Individuals } \\
\text { Included in Target } \\
\text { Population }\end{array}$ & $\begin{array}{c}\text { Reported Outcomes/Or } \\
\text { Advocate } \\
\text { Evidence-Backed } \\
\text { Approach }\end{array}$ & $\begin{array}{l}\text { Reproducible (As } \\
\text { Mentioned in } \\
\text { Publication) }\end{array}$ & $\begin{array}{l}\text { Theoretical } \\
\text { Underpinning }\end{array}$ \\
\hline $0=$ not specified & $\mathrm{NA}=$ not applicable & $\mathrm{NA}=$ not applicable & $1=$ no & $1=$ no & $1=$ not mentioned & $\begin{array}{l}\mathrm{NA}=\text { not } \\
\text { applicable }\end{array}$ \\
\hline $\begin{array}{c}1=\text { review/description } \\
\text { (no data) }\end{array}$ & $1=<10$ & $\begin{array}{c}\mathrm{C}=\text { cross-sectional } \\
\text { design }\end{array}$ & $2=$ yes & $2=$ yes & $2=$ can be reproduced & $\begin{array}{c}1=\text { not present in } \\
\text { publication }\end{array}$ \\
\hline $\begin{array}{l}2=\text { qualitative or } \\
\text { quantitative data }\end{array}$ & $2=11-50$ & $1=$ days & & & & $\begin{array}{l}2=\text { presented in } \\
\text { publication }\end{array}$ \\
\hline $3=$ mixed methods & $3=51-100$ & $2=$ weeks & & & & \\
\hline $\begin{array}{l}4=\text { experimental study } \\
\text { (randomized, controlled, } \\
\text { or pre-post-test design) }\end{array}$ & $\begin{array}{c}4=>100 \text { or } \leq 10 \\
\text { papers (for reviews) }\end{array}$ & $3=$ months & & & & \\
\hline $5=$ literature review & $\begin{array}{c}5=>1000 \text { or }>10 \\
\text { papers (for reviews) }\end{array}$ & $4=1-5$ years & & & & \\
\hline $\mathrm{P}=$ pilot study & & $5=>5$ years & & & & \\
\hline
\end{tabular}




\section{Results}

From our systematic database search, we retrieved 3054 unique records (Figure 1). Close screening of titles and abstracts narrowed the full text number down to 280 publications, including 22 abstracts and conference proceedings that were subsequently removed as they were not followed by any full-text publication. Based on the predefined inclusion and exclusion criteria, a total of 118 publications remained for data extraction. A full overview of the selection process is presented in Figure 1.

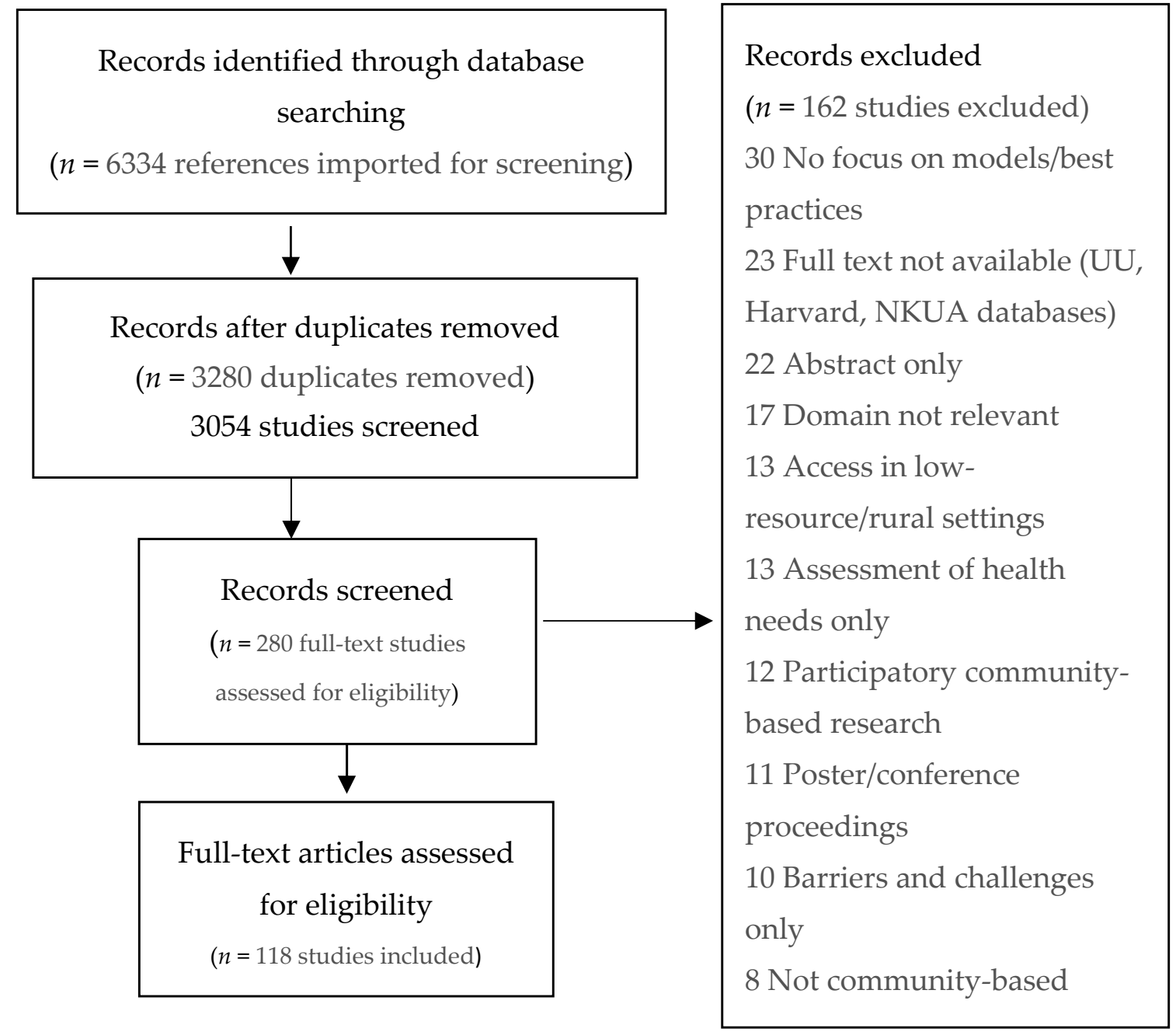

Figure 1. PRISMA flow diagram for Mig-HealthCare systematic database search.

\subsection{Overall Study Characteristics}

Out of 118 records, 53 (44.5\%) discussed mental health, 36 (29.4\%) community-based health services, 13 (10.9\%) noncommunicable diseases (excluding mental health), 9 (7.6\%) primary healthcare, and $7(5.9 \%)$, maternal/women's health and child health.

Countries or regions of implementation included: North America (United States and Canada), 67/118 (56.7\%), Europe, 28/118 (23.7\%), Australia and New Zealand, 9/118 (7.6\%), the Middle East, 6/118 (5.1\%), Asia, 2/118 (1.7\%), and Latin America, 1/118 (<1\%). Five records did not specify the area of implementation. Populations targeted included migrants, immigrants, refugees, asylum-seekers, and racial and ethnic minorities, as defined by the respective authors. All these subgroups are part of the larger definition of migrants/refugees. Some publications targeted specific population groups such as women, children, adolescents, or families; elderly patients; trauma- or torture-exposed individuals; seasonal/farm workers; or individuals with a low income. Ethnicity or country of origin of the target 
population groups was mentioned in some, but not all, publications. Study designs included mostly mixed methods (use of quantitative and qualitative data); qualitative research (interviews and focus groups); surveys; and, less frequently, experimental designs (controlled, randomized, or pre-post-test designs). Most experimental studies were labeled as pilot studies. Community aspects were framed as either interventions implemented in the migrant community or as models or programs that rely on the engagement of different community stakeholders (such as universities, schools, and different community health services). The vast majority of studies (105 out of 118) were published between 2006 and 2018 (89\%). A distinction between single and complex interventions was also made. By complex interventions, we mean activities (models or programs) that contain a number of component parts (interventions) with the potential for interactions between them that, when applied to the intended target population, produce a range of possible and variable outcomes [10]. Due to their nature, the effectiveness of complex interventions are more difficult to substantiate.

\subsection{Identified Best Practices According to Thematic Area of the Reviewed Records}

\subsubsection{Mental Health}

Published interventions on mental health were carried out primarily in the USA (25/53), Europe (12/53), and Canada (8/53) and less in the Middle East (2/53), Australia (2/53), and Asia (1/53). Dates of publication varied from 2002 to 2018, with 48/53 published in the period of 2005-2017. Target populations involved refugees (in some studies, further specified as of particular descent, children, tortured, newly arrived, families, and multi-ethnic adults); minorities (elderly, ethnic, low-income, and racial); immigrants (traumatized children and adolescents, women, low-income, and of specific/varying descent); asylum-seekers; and migrants (of specific descent, youth, children, and families).

Single interventions described for community-based mental health services pertained to the training of (future) healthcare workers and cultural brokering [11-63]. Training programs refer to the cross-cultural understanding and competency of healthcare workers [11,12] and the training and delivery of healthcare services among psychology or nursing students [14,15]. In terms of "cultural brokering" [12], community peers [17-21], bilingual gatekeepers [22], and ethnic matching of therapists and patients $[13,24]$ were identified. Complex interventions constitute school-based programs to screen (and sometimes, also to treat) children and adolescents from migrant and refugee communities for mental health problems [16,25-29], mental health promotion in community day centers [30,31], and by community organizations [32,33] and various other community-based mental health services [30-37]. Screening tools for psychosocial risk assessments were also used [20,42,43].

Core elements of the identified interventions and models were: partnering with members from target communities [44,45]; community mobilization to stimulate outreach [33,46,47]; culturally and linguistically sensitive approaches [14,45,47-53]; education of health service providers on the needs of the target population [13,40,54]; awareness raising on mental health [46,55]; availability of information in relevant languages [44]; advocacy [56,57]; facilitating better integration [52]; responsiveness, coordination, and planning of different health and social services $[12,54,55,58,59]$; establishing a sense of belonging, community, and trust [18,58,59]; promoting empowerment and cultural competency [19,61,62]; funding [58]; and community-based participatory research [47].

\subsubsection{Health Services}

Publications in this category are studies focusing on health promotion and access to care, mainly implemented in the USA (19/36), Europe (12/36), and Canada (2/36), and in Australia (2/36) and Asia (1/36), mostly in between 2007-2018 [64-99]. The populations addressed included racial and ethnic minorities; migrants (further specified as elderly, farm workers, or irregular); refugees (Syrian, apartment-dwelling, youth, older adult, and more); immigrants (elderly or recent); and minority children. It must be noted that the term "health services" in this review refers to all services related to 
health in general and not necessarily delivered within the healthcare system of which primary health care is an integral part.

Single interventions that emerged constituted of: providing health information [64,65], cultural brokering through ambassadors [66-72], bilingual advocacy and interpretation [73,74], and a community garden project addressing a sense of community and adoption of a healthy dietary pattern [75]. Complex interventions, on the other hand, concerned community-academic partnerships [76-81], community-based nursing initiatives [82-84], home-based health services [83], programs on prevention, and healthcare services for the uninsured [85].

Prevalent aspects of interventions were: supervision and responsibility of stakeholders to provide equity, cultural, and linguistic competence in healthcare access and delivery [86,87]; creating a sense of community and commitment; obligation of stakeholders [68,86-88]; community-based leadership that is transferring the operational supervision of the intervention to the local level to facilitate sustainability $[79,89]$; social networking viewed as a necessary skill along with good communication to improve the efficiency of the intervention [89,90]; and evidence-based guidelines [91,92].

Additionally, reducing discrimination [92]; the promotion of understanding of human values [84,93]; targeted outreach strategies with specific focus on health education, health promotion, disease screening, and prevention [94]; community collaboration and advocacy [74,88,91,93-96]; raising awareness on health risks [85,86,95]; and culturally and linguistically sensitive approaches $[69,71,73,74,85,87,88,91,94,97,99]$.

Finally, building trust between migrants and service providers $[77,81,84]$, educating service providers on the health needs of the community $[77,79,81,85,90]$, warranting the availability of resources [85,97] and sustainability of the programs [79,91], surveillance, and the evaluation of interventions $[79,88,92]$.

\subsubsection{Noncommunicable Diseases}

Studies were conducted from 2012 to 2017 (12/13) in the USA (5/13), Europe (2/13), multiple countries (2/13), Canada, Australia, Middle East, and Latin America [100-112]. Target populations pertained to immigrants (mostly women of various descents), refugees, migrants, and ethnic minorities, some of which were further defined as diabetic.

Community-based strategies for the management of the following were discussed: cancer screening [100-104], diabetes mellitus [99,105-108], cardiovascular disease prevention [109,110], and other chronic diseases [111,112]. Cancer-mostly breast cancer-prevention tools involved culturally tailored, narrative educational videos [100], pictograph-enhanced instructions [102], and patient-centered strategies [103,104]. The latter was also applied in diabetes mellitus management [106]. Diabetes mellitus and cardiovascular disease prevention interventions were culturally tailored approaches and story-telling [98,103-105,107-109].

Core elements of the described practices are culturally and linguistically sensitive education [103,104,109,112], involvement and support of the migrant communities' infrastructures [110], awareness-raising about health risks [101], outreach approaches through families and community peers $[101,105,111]$, facilitating the "community voice", intersectional collaboration, and funding [101].

\subsubsection{Primary Healthcare}

Publications in this area of action were conducted mainly between 2012 and 2018 (7/9) in Australia (2/9), the USA (2/9), Canada (2/9), and the Middle East (1/9) (+2/9 not specified), and populations addressed included refugees and asylum-seekers, immigrants of various descents, and vulnerable migrants [113-121]. Aspects of the interventions in primary healthcare discussed are engagement with the migrant community through partnerships [113,114], stronger focus on ancillary services [121], interdisciplinary collaboration between public health and primary care institutions [116-118], culturally and linguistically trained interpreters [118,119], evidence-based guidelines $[118,119]$, outreach activities 
by nurses [120], training of staff in cultural competency [114,121], health promotion education among migrants, and advocacy $[117,121]$.

\subsubsection{Maternal, Women's and Child Health}

Six of the seven identified records were carried out from 2001 to 2015 (1/7 in 1989) in the USA (3/7), Australia (2/7), Canada, and the Middle East (1/7). Target populations involved refugees (in certain studies, further defined as Syrian, children, and parents); immigrants; racial; and ethnic minority women [122-128].

The main focus of interventions in this area was the reduction of maternal and child health inequalities among migrant/refugee communities, mostly through publicly funded universal health activities [122] and government-led approaches [123]. Committed community and health service provider (agencies) partnerships through multiple mobilization strategies were considered successful for improving the health of pregnant women [124]. Capacity-building, as in ways to address barriers in healthcare provisions for minority populations, such as health insurance availability, healthcare cost reimbursement, healthcare advice in a native language, and culturally sensitive training of healthcare professionals, is essential; to maintain the interests of service providers and community members is essential for program sustainability. In general, partnerships between the target community and the different local healthcare providers are recommended to identify the barriers faced by women and potential solutions for improving access to care [125]. Intensive child health promotion and education campaigns using ethnic media (radio, TV channels, and newsletters in the native language of the beneficiaries) and social networking were observed to positively affect parental awareness, knowledge, and beliefs about infectious disease prevention in children [126].

For individuals with additional health needs, such as those requiring prenatal or pediatric care, a Culturally Appropriate Resources and Education (C.A.R.E.) Clinic Health Advisor is recommended for specialty clinics. This type of health advisor facilitates communication, establishes a sense of community, and helps patients navigate the healthcare system [127]. To implement reproductive health services in humanitarian emergencies, facilitators are a pre-existing functioning health infrastructure, with prior training in their particular type of service delivery, dedicated leadership, and the availability of sufficient funding and resources [128].

\subsection{Promising Best Practices at the Community Level}

Our assessment prioritized the 15 top best practices according to the set criteria. The top scores were 20 points ( 1 publication), 19 points (1), 18 points (1), 17 points (4), 16 points (1), and 15 points (7 publications). These 15 interventions best fit the set evaluation criteria and are presented as the most promising. In terms of the area of action, they are categorized as follows: seven in mental health, two in health service provision, two in noncommunicable diseases, two in primary healthcare, and two in maternal health (Table 2).

The training of health professionals, close collaborations of stakeholders, partnerships, social networks, linguistically and culturally sensitive service provisions, participatory approaches, and advocacy are elements described in these promising best practices. 
Table 2. The 15 highly assessed best practices.

\begin{tabular}{|c|c|c|c|c|}
\hline Publication & $\begin{array}{l}\text { Reference } \\
\text { Number }\end{array}$ & $\begin{array}{c}\text { Area of } \\
\text { Intervention }\end{array}$ & Intervention & Score \\
\hline McMurray (2014) & [116] & Primary healthcare & $\begin{array}{l}\text { Partnership between a dedicated health clinic for } \\
\text { government-assisted refugees, a local reception } \\
\text { center, and community providers }\end{array}$ & 20 \\
\hline Reavy (2012) & [127] & Maternal health & $\begin{array}{l}\text { New clinic model for prenatal and pediatric } \\
\text { refugee patients (in particular, the role of the } \\
\text { Culturally Appropriate Resources and Education } \\
\text { (C.A.R.E.) Clinic Health Advisor) }\end{array}$ & 19 \\
\hline Small (2016) & [38] & Mental health & $\begin{array}{l}\text { Comparison of three different treatment modalities: } \\
\text { treatment as usual (TAU), home-based counseling } \\
\text { (HBC), and a community-based } \\
\text { psycho-educational group (CPG) }\end{array}$ & 18 \\
\hline Bader (2006) & [109] & $\begin{array}{l}\text { Noncommunicable } \\
\text { Diseases }\end{array}$ & $\begin{array}{c}\text { Linguistically and culturally sensitive } \\
\text { cardiovascular disease (CVD) prevention program }\end{array}$ & 17 \\
\hline $\begin{array}{c}\text { Sheikh \& } \\
\text { McIntyre (2002) }\end{array}$ & [126] & Maternal health & $\begin{array}{l}\text { Intensive child health promotion and education } \\
\text { campaign using ethnic media and social network }\end{array}$ & 17 \\
\hline $\begin{array}{c}\text { Williams \& } \\
\text { Thompson (2011) }\end{array}$ & [40] & Mental health & Community-based mental healthcare services & 17 \\
\hline Kaltman (2011) & [37] & Mental health & $\begin{array}{l}\text { Collaborative mental healthcare program } \\
\text { implemented in a network of primary care clinics } \\
\text { that serve the uninsured }\end{array}$ & 17 \\
\hline $\begin{array}{l}\text { Fondacarro } \\
\quad(2016)\end{array}$ & [14] & Mental health & $\begin{array}{l}\text { Training program for psychology students } \\
\text { (“Connecting Cultures”) }\end{array}$ & 16 \\
\hline $\begin{array}{l}\text { Levin-Zamir } \\
\quad(2011)\end{array}$ & [114] & Primary healthcare & $\begin{array}{l}\text { Cross-cultural program for promoting } \\
\text { communication and health }\end{array}$ & 15 \\
\hline Siddaiah (2014) & [112] & $\begin{array}{l}\text { Noncommunicable } \\
\text { Diseases }\end{array}$ & $\begin{array}{l}\text { Community-based, culturally competent } \\
\text { respiratory health screening and education }\end{array}$ & 15 \\
\hline $\begin{array}{l}\text { Tumiel-Behalter } \\
\text { (2011) }\end{array}$ & [89] & $\begin{array}{l}\text { Health service } \\
\text { provision }\end{array}$ & $\begin{array}{l}\text { Community program with a participatory } \\
\text { approach to improve the health of four } \\
\text { underserved communities ("Good For The } \\
\text { Neighborhood") }\end{array}$ & 15 \\
\hline Ferrera (2017) & [96] & $\begin{array}{l}\text { Health service } \\
\text { provision }\end{array}$ & $\begin{array}{l}\text { Health promotion initiative that integrates } \\
\text { principles of positive minority youth development }\end{array}$ & 15 \\
\hline $\begin{array}{l}\text { Tyrer \& Fazel } \\
\quad(2014)\end{array}$ & [29] & Mental health & School and community-based interventions & 15 \\
\hline Kaltman (2016) & [36] & Mental health & $\begin{array}{l}\text { Mental health intervention for primary care clinics } \\
\text { that serve the uninsured }\end{array}$ & 15 \\
\hline Goodkind (2014) & [56] & Mental health & $\begin{array}{c}\text { Community-based advocacy and learning } \\
\text { intervention with refugees and undergraduate } \\
\text { students }\end{array}$ & 15 \\
\hline
\end{tabular}

\section{Discussion}

This study reviewed the academic literature for best practices in community healthcare models for migrants and refugees.

We developed an evaluation tool to assess and classify the search results for their scientific robustness based on their reported characteristics, such as population size, type of intervention, achieved outcome, reproducibility, and theoretical underpinning.

In the final set of identified practices, five areas of action were identified: mental health, health services, noncommunicable diseases, primary healthcare, and maternal women's and child health. All publications were thoroughly assessed per category, and then, based on the evaluation ranking (a numerical score), the identified interventions/best practices were prioritized in terms of scientific soundness and reproducibility potential. Partnerships between governments and community providers, the design and delivery of tailor-made educational activities for children, linguistically and culturally 
adapted disease prevention activities, and community and school-based interventions for mental health addressing various population groups, as well as training programs for future healthcare professionals have been shown to be efficient and reproducible ways to improve the health of vulnerable population groups such as refugees and migrants.

\section{Challenges-Limitations}

1. This review is a comprehensive effort to identify community-based best practices at the primary healthcare level, addressing refugees and migrants in the peer-reviewed literature with the aim to provide information and guidance to the health professionals working at the primary healthcare level primarily in the EU Member States. This effort encountered several challenges/limitations. There is an abundance of publications regarding interventions for migrant/refugee healthcare in the peer-reviewed literature. A huge variation in the meaning of the terms community, community health or healthcare, and best practice was identified, along with an interchangeable use of the terms migrants and refugees, as well as immigrants, minorities, and asylum-seekers.

2. The majority of publications (64.3\%) originated from the US, Canada, and Australia, addressing, by large, refugees and migrants at a much-progressed social integration stage compared to Europe and from very different ethnic backgrounds.

3. Many publications did not specify ethnicity; country of origin; or specific characteristics (i.e., age or social determinants) of the target population.

4. Despite the richness of published information, it should be noted that multiple other interventions exist that have not (and may never) been published through a peer-review process, due to numerous reasons spanning from lower prioritization of the health issue to lack of resources to cover publications fees. Certainly, there can be areas of migrant/refugee health that could not be retrieved in the literature prior to March 2018, as no relevant publications were available. However, after reviewing some abstracts and conference proceedings, we have strong reasons to believe that many interventions delivered as pilot studies have not been published as full-text papers, despite the fact that they provide valuable insights into potentially effective community-based interventions.

Evidently, such issues are not of lesser importance compared to the published ones. In this aspect, it is important to note that studies on migrant/refugee health issues may never materialize into a peer-reviewed publication, as they often face several barriers such as the scarcity of systematically recorded data on migrant/refugee health and a reluctance of vulnerable populations to participate in interventions stemming from communication difficulties to legal issues of residence and social exclusion, resulting in small participation rates and study samples or a difficulty in monitoring health in populations on the move, as they often change locations or even countries.

The objective of the present review was to identify the best practices and tools of community-based interventions for migrants/refugees, and as such, a set of 15 practices addressing the areas of mental health, primary healthcare, health service provision, and noncommunicable disease management and prevention strategies, as well as maternal and child health, were identified based on specific evaluation criteria.

The majority of projects, activities, and interventions identified in this review focus on the area of mental health, and this is an important finding that needs to be examined further, as there could be a multitude of reasons for this. The area of health service provision is also important, as well as the issue of chronic disease management, which poses as a major future challenge for healthcare systems. The primary healthcare setting is vital, as it has close links to the community and facilitates the involvement of the local population in preventing and managing diseases. It is important to note that, in almost all of the sources identified, the elements of good communication, the linguistic barriers, and the cultural elements played crucial roles in the effective applications of the interventions. Evidently, the close collaborations of the various stakeholders, the local communities, the migrant/refugee 
communities, and the partnerships are key elements in the successful implementation of effective primary healthcare provisions.

\section{Conclusions}

The provision of essential health services of good quality for all population groups of a society is described in the 2030 Agenda for Sustainable Development [129]. These services, as emerged from our scoping review, include health promotion, disease prevention, and disease-management activities and should aim to meet the needs of all people, especially migrants, refugees, and the vulnerable. Primary healthcare services offered at the community level can cover all aspects of health-related needs and are very effective in addressing the health needs and challenges of all.

Author Contributions: E.R., conceptualization, methodology, publication selection and review, and evaluation criteria; S.K. (Shona Kalkman), search strategy, publication selection and review, and evaluation criteria; A.C., evaluation of mental health publications; S.K. (Sotirios Koubardas), original draft preparation; S.V., evaluation of primary healthcare and maternal and child health publications; D.L., writing-Review and editing; P.K., project administration; D.Z., appraisal of best practices; M.K., evaluation of noncommunicable diseases and of health service publications; T.P., writing-Review and editing; and A.L., funding acquisition. All authors have read and agreed to the published version of the manuscript.

Funding: This scoping review forms a part of the tasks described in the EU project "Strengthen Community Based Care to minimize health inequalities and improve the integration of vulnerable migrants and refugees into local communities". This project received partial funding from the European Union's Health Programme (2014-2020) Consumers, Health, Agriculture and Food Executive Agency (CHAFEA), Grant Agreement 738186, Acronym Mig-HealthCare.

Acknowledgments: The authors would like to thank the Mig-HealthCare Partner Consortium (www. mighealthcare.eu) for the fruitful collaboration in the project implementation.

Conflicts of Interest: The authors declare no conflicts of interest. The funders (European Commission) had no role in the design of the study; in the collection, analyses, or interpretation of data; in the writing of the manuscript; or in the decision to publish the results.

\section{References}

1. United Nations High Commission for Refugees (UNHCR). Operational Data Portal. Available online: https://data2.unhcr.org/en/situations/mediterranean (accessed on 17 April 2020).

2. Matlin, S.A.; Depoux, A.; Schütte, S.; Flahaust, A.; Saso, L. Migrants' and refugees' health: Towards an agenda of solutions. Public Health Rev. 2018, 39, 27. [CrossRef]

3. WHO Regional Office for Europe Report on the Health of Refugees and Migrants in the WHO European Region. No PUBLIC HEALTH without REFUGEE and MIGRANT HEALTH—Summary. 2018. Available online: https://apps.who.int/iris/bitstream/handle/10665/311348/9789289053785-eng.pdf?sequence= 1\&isAllowed=y (accessed on 17 April 2020).

4. WHO Regional Office for Europe. Health Promotion for Improved Refugee and Migrant Health. Copenhagen; (Technical Guidance on Refugee and Migrant Health). 2018. Available online: http://www.euro.who.int/_ data/assets/pdf_file/0004/388363/tc-health-promotion-eng.pdf?ua=1\&ua=1 (accessed on 14 February 2020).

5. MigHelthCare Minimize Health Inequalities and Improve the Integration of Vulnerable Migrants and Refugees into Local Communities. Available online: https://www.mighealthcare.eu/ (accessed on 26 April 2020).

6. Green, L.W.; Ottoson, J.M. Community and Population Health, 8th ed.; WCB/McGraw-Hill: Boston, MA, USA, 1999; Volume 4, pp. 41-42.

7. McKenzie, J.F.; Pinger, R.R.; Kotecki, J.E. An Introduction to Community Health; Jones and Bartlett Publishers: Boston, MA, USA, 2005; p. 5.

8. United Nations High Commission for Refugees (UNHCR). Refugees and Migrants. Available online: https://refugeesmigrants.un.org/definitions (accessed on 26 April 2020).

9. Moher, D.; Liberati, A.; Tetzlaff, J.; Altman, D.G. Preferred Reporting Items for Systematic Reviews and Meta-Analyses: The PRISMA Statement. PLoS Med. 2009, 6, e1000097. [CrossRef] [PubMed] 
10. Norris, S.L.; Rehfuess, E.A.; Smith, H.; Tunçalp, Ö.; Grimshaw, J.M.; Ford, N.P.; Portela, A. Complex health interventions in complex systems: Improving the process and methods for evidence-informed health decisions. BMJ Glob. Health 2019, 4, e000963. [CrossRef] [PubMed]

11. Baarnhielm, S.; Edlund, A.S.; Ioannou, M.; Dahlin, M. Approaching the vulnerability of refugees: Evaluation of cross-cultural psychiatric training of staff in mental health care and refugee reception in Sweden. BMC Med. Educ. 2014, 14, 207. [CrossRef]

12. Misra, T.; Connolly, A.M.; Klynman, N.; Majeed, A. Addressing mental health needs of asylum seekers and refugees in a London Borough: Developing a service model. Prim. Health Care Res. Dev. 2006, 7, 249-256.

13. Moore, D.E.; Overstreet, K.M.; Like, R.C.; Kristofco, R.E. Improving Depression Care for Ethnic and Racial Minorities: A Concept for an Intervention that Integrates CME Planning with Improvement Strategies. J. Contin. Educ. Health Prof. 2007, 27, S65-S74. [CrossRef]

14. Fondacaro, K.M.; Harder, V.S. Connecting cultures: A training model promoting evidence-based psychological services for refugees. Train. Educ. Prof. Psychol. 2014, 8, 320-327. [CrossRef]

15. Hess, J.M.; Isakson, B.; Githinji, A.; Roche, N.; Vadnais, K.; Parker, D.P.; Goodkind, J.R. Reducing mental health disparities through transformative learning: A social change model with refugees and students. Psychol. Serv. 2014, 11, 347-356. [CrossRef]

16. Brar-Josan, N.; Yohani, S.C. Cultural brokers' role in facilitating informal and formal mental health supports for refugee youth in school and community context: A Canadian case study. Br. J. Guid. Couns. 2017, 47, 512-523. [CrossRef]

17. Behnia, B. Refugees' Convoy of Social Support: Community Peer Groups and Mental Health Services. Int. J. Ment. Health 2004, 32, 6-19. [CrossRef]

18. Im, H.; Rosenberg, R. Building Social Capital Through a Peer-Led Community Health Workshop: A Pilot with the Bhutanese Refugee Community. J. Community Health 2016, 41, 509-517. [CrossRef] [PubMed]

19. Kieft, B.; Jordans, M.J.; de Jong, J.T.; Kamperman, A.M. Paraprofessional counselling within asylum seekers' groups in the Netherlands: Transferring an approach for a non-western context to a European setting. Transcult. Psychiatry 2008, 45, 105-120. [CrossRef] [PubMed]

20. Llosa, A.E.; Van Ommeren, M.; Kolappa, K.; Ghantous, Z.; Souza, R.; Bastin, P.; Slavuckij, A.; Grais, R.F. A two-phase approach for the identification of refugees with priority need for mental health care in Lebanon: A validation study. BMC Psychiatry 2017, 17. [CrossRef] [PubMed]

21. Tran, A.N.; Ornelas, I.J.; Kim, M.; Perez, G.; Green, M.; Lyn, M.J.; Corbie-Smith, G. Results from a pilot promotora program to reduce depression and stress among immigrant Latinas. Health Promot. Psychol. 2014, 15, 365-372. [CrossRef]

22. Choi, Y.-J. Effects of a Program to Improve Mental Health Literacy for Married Immigrant Women in Korea. Arch. Psychiatr. Nurs. 2017, 31, 394-398. [CrossRef] [PubMed]

23. Knipscheer, J.W.; Kleber, R.J. A need for ethnic similarity in the therapist-patient interaction? Mediterranean migrants in Dutch mental-health care. J. Clin. Psychol. 2004, 60, 543-554. [CrossRef]

24. Snowden, L.; Masland, M.; Ma, Y.; Ciemens, E. Strategies to improve minority access to public mental health services in California: Description and preliminary evaluation. J. Community Psychol. 2006, 34, 225-235. [CrossRef]

25. Beehler, S.; Birman, D.; Campbell, R. The Effectiveness of Cultural Adjustment and Trauma Services (CATS): Generating practice-based evidence on a comprehensive, school-based mental health intervention for immigrant youth. Am. J. Community Psychol. 2012, 50, 155-168. [CrossRef]

26. Chiumento, A.; Nelki, J.; Dutton, C.; Hughes, G. School-based mental health service for refugee and asylum seeking children: Multi-agency working, lessons for good practice.Emerald Insight. J. Public Ment. Health 2011, 10, 164-177. [CrossRef]

27. Ellis, B.H.; Miller, A.B.; Abdi, S.; Barrett, C.; Blood, E.A.; Betancourt, T.S. Multi-tier mental health program for refugee youth. J. Consult. Clin. Psychol. 2013, 81, 129-140. [CrossRef]

28. Stein, B.D.; Kataoka, S.; Jaycox, L.H.; Wong, M.; Fink, A.; Escudero, P.; Zaragoza, C. Theoretical basis and program design of a school-based mental health intervention for traumatized immigrant children: A collaborative research partnership. J. Behav. Health Serv. Res. 2002, 29, 318-326. [CrossRef] [PubMed]

29. Tyrer, R.A.; Fazel, M. School and community-based interventions for refugee and asylum seeking children: A systematic review. PLoS ONE 2014, 9, e97977. [CrossRef] 
30. Chase, L.E.; Rousseau, C. Ethnographic case study of a community day center for asylum seekers as early stage mental health intervention. Am. J. Orthopsychiatry 2018, 88, 48-58. [CrossRef] [PubMed]

31. Gionakis, N.; Stylianidis, S. Community mental healthcare for migrants. In Social and Community Psychiatry: Towards a Critical, Patient-Oriented Approach; Stylianidis, S., Ed.; Springer International Publishing: Cham, Switzerland, 2016; pp. 309-329. [CrossRef]

32. Arean, P.A.; Ayalon, L.; Jin, C.; McCulloch, C.E.; Linkins, K.; Chen, H.; McDonnell-Herr, B.; Levkoff, S.; Estes, C. Integrated specialty mental health care among older minorities improves access but not outcomes: Results of the PRISMe study. Int. J. Geriatr. Psychiatry 2008, 23, 1086-1092. [CrossRef]

33. Koehn, S.D.; Jarvis, P.; Sandhra, S.K.; Bains, S.K.; Addison, M. Promoting mental health of immigrant seniors in community. Ethn. Inequalities Health Soc. Care 2014, 7, 146-156. [CrossRef]

34. Birman, D.; Beehler, S.; Harris, E.M.; Everson, M.L.; Batia, K.; Liautaud, J.; Frazier, S.; Atkins, M.; Blanton, S.; Buwalda, J.; et al. International Family, Adult, and Child Enhancement Services (FACES): A community-based comprehensive services model for refugee children in resettlement. Am. J. Orthopsychiatry 2008, 78, 121-132. [CrossRef]

35. Dura-Vila, G.; Klasen, H.; Makatini, Z.; Rahimi, Z.; Hodes, M. Mental health problems of young refugees: Duration of settlement, risk factors and community-based interventions. Clin. Child Psychol. Psychiatry 2013, 18, 604-623. [CrossRef] [PubMed]

36. Kaltman, S.; Hurtado de Mendoza, A.; Serrano, A.; Gonzales, F.A. A mental health intervention strategy for low-income, trauma-exposed Latina immigrants in primary care: A preliminary study. Am. J. Orthopsychiatry 2016, 86, 345-354. [CrossRef] [PubMed]

37. Kaltman, S.; Pauk, J.; Alter, C.L. Meeting the mental health needs of low-income immigrants in primary care: A community adaptation of an evidence-based model. Am. J. Orthopsychiatry 2011, 81, 543-551. [CrossRef]

38. Small, E.; Kim, Y.K.; Praetorius, R.T.; Mitschke, D.B. Mental health treatment for resettled refugees: A comparison of three approaches. Soc. Work Ment. Health 2016, 14, 342-359. [CrossRef]

39. Tse, S.; Divis, M.; Li, Y.B. Match or mismatch: Use of the strengths model with chinese migrants experiencing mental illness: Service user and practitioner perspectives. Am. J. Psychiatr. Rehabil. 2010, 13, 171-188. [CrossRef]

40. Williams, M.E.; Thompson, S.C. The use of community-based interventions in reducing morbidity from the psychological impact of conflict-related trauma among refugee populations: A systematic review of the literature. J. Immigr. Minority Health 2011, 13, 780-794. [CrossRef] [PubMed]

41. Xin, H.; Bailey, R.; Jiang, W.; Aronson, R.; Strack, R. A pilot intervention for promoting multiethnic adult refugee groups' mental health: A descriptive article. J. Immigr. Refug. Stud. 2011, 9, 291-303. [CrossRef]

42. Ahmad, F.; Shakya, Y.B.; Li, J.; Khoaja, K.; Norman, C.; Lou, W.; Abuelaish, I.; Ahmadzi, H.M. A pilot with computer-assisted psychosocial risk-assessment for refugees. BMC Med. Inform. Decis. Mak. 2012, $12,71$. [CrossRef]

43. Polcher, K.; Calloway, S. Addressing the Need for Mental Health Screening of Newly Resettled Refugees: A Pilot Project. J. Prim. Care Community Health 2016, 7, 199-203. [CrossRef]

44. Bhattacharyya, S.; Benbow, S.M. Mental health services for black and minority ethnic elders in the United Kingdom: A systematic review of innovative practice with service provision and policy implications. Int. Psychogeriatr. 2013, 25, 359-373. [CrossRef] [PubMed]

45. Hamilton, J.; Begley, C.; Culler, R. Evaluation of partner collaboration to improve community-based mental health services for low-income minority children and their families. Eval. Program Plan. 2014, 45, 50-60. [CrossRef] [PubMed]

46. Harris, K.; Maxwell, C. A needs assessment in a refugee mental health project in north-east London: Extending the counselling model to community support. Med. Confl. Surviv. 2000, 16, 201-215. [CrossRef]

47. Weine, S.M. Developing preventive mental health interventions for refugee families in resettlement. Fam. Process 2011, 50, 410-430. [CrossRef]

48. Fernando, S. Multicultural mental health services: Projects for minority ethnic communities in England. Transcult. Psychiatry 2005, 42, 420-436. [CrossRef]

49. Khawaja, N.G.; Stein, G. Psychological Services for Asylum Seekers in the Community: Challenges and Solutions. Aust. Psychol. 2016, 51, 463-471. [CrossRef] 
50. Lee, H.B.; Hanner, J.A.; Cho, S.-J.; Han, H.-R.; Kim, M.T. Improving Access to Mental Health Services for Korean American Immigrants: Moving Toward a Community Partnership Between Religious and Mental Health Services. Psychiatry Investig. 2008, 5, 14. [CrossRef] [PubMed]

51. Nazzal, K.H.; Forghany, M.; Geevarughese, M.C.; Mahmoodi, V.; Wong, J. An innovative community-oriented approach to prevention and early intervention with refugees in the United States. Psychol. Serv. 2014, 11, 477-485. [CrossRef] [PubMed]

52. Price, O.A.; Ellis, B.H.; Escudero, P.V.; Huffman-Gottschling, K.; Sander, M.A.; Birman, D. Implementing trauma interventions in schools: Addressing the immigrant and refugee experience. Adv. Educ. Divers. Communities Res. Policy Prax. 2012, 9, 95-119. [CrossRef]

53. Sturm, G.; Guerraoui, Z.; Bonnet, S.; Gouzvinski, F.; Raynaud, J.P. Adapting services to the needs of children and families with complex migration experiences: The Toulouse University Hospital's intercultural consultation. Transcult. Psychiatry 2017, 54, 445-465. [CrossRef]

54. Nadeau, L.; Measham, T. Immigrants and mental health services: Increasing collaboration with other service providers. Can. Child Adolesc. Psychiatry Rev. 2005, 14, 73-76.

55. Priebe, S.; Matanov, A.; Schor, R.; Straßmayr, C.; Barros, H.; Barry, M.; Díaz-Olalla, J.M.; Gabor, E.; Greacen, T.; Holcnerová, P.; et al. Good practice in mental health care for socially marginalised groups in Europe: A qualitative study of expert views in 14 countries. BMC Public Health 2012, 12. [CrossRef]

56. Goodkind, J.R.; Hess, J.M.; Isakson, B.; LaNoue, M.; Githinji, A.; Roche, N.; Vadnais, K.; Parker, D.P. Reducing refugee mental health disparities: A community-based intervention to address postmigration stressors with African adults. Psychol. Serv. 2014, 11, 333-346. [CrossRef]

57. Law, $\mathrm{S}$. The role of a clinical director in developing an innovative assertive community treatment team targeting ethno-racial minority patients. Psychiatr. Q. 2007, 78, 183-192. [CrossRef]

58. Nadeau, L.; Jaimes, A.; Johnson-Lafleur, J.; Rousseau, C. Perspectives of Migrant Youth, Parents and Clinicians on Community-Based Mental Health Services: Negotiating Safe Pathways. J. Child Fam. Stud. 2017, 26, 1936-1948. [CrossRef]

59. Sijbrandij, M.; Acartürk, C.; Bird, M.; Bryant, R.A.; Burchert, S.; Carswell, K.; De Jong, J.; Dinesen, C.; Dawson, K.S.; El Chammay, R.; et al. Strengthening mental health care systems for Syrian refugees in Europe and the Middle East: Integrating scalable psychological interventions in eight countries. Eur. J. Psychotraumatol. 2017, 8, 1388102. [CrossRef] [PubMed]

60. Murray, K.E.; Davidson, G.R.; Schweitzer, R.D. Review of refugee mental health interventions following resettlement: Best practices and recommendations. Am. J. Orthopsychiatry 2010, 80, 576-585. [CrossRef] [PubMed]

61. Chen, Y.Y.B.; Li, A.T.; Fung, K.P.; Wong, J.P. Improving Access to Mental Health Services for Racialized Immigrants, Refugees, and Non-Status People Living with HIV/AIDS. J. Health Care Poor Underserved 2015, 26, 505-518. [CrossRef]

62. Holden, K.B.; McGregor, B.; Thandi, P.; Fresh, E.; Sheats, K.; Belton, A.; Mattox, G.; Satcher, D. Toward culturally centered integrative care for addressing mental health disparities among ethnic minorities. Psychol. Serv. 2014, 11, 357-368. [CrossRef]

63. McBride, J.; Russo, A.; Block, A. The Refugee Health Nurse Liaison: A nurse led initiative to improve healthcare for asylum seekers and refugees. Contemp. Nurse 2016, 52, 710-721. [CrossRef]

64. Cortinois, A.A.; Glazier, R.H.; Caidi, N.; Andrews, G.; Herbert-Copley, M.; Jadad, A.R. Toronto's 2-1-1 healthcare services for immigrant populations. Am. J. Prev. Med. 2012, 43, S475-S482. [CrossRef] [PubMed]

65. Dutcher, G.A.; Scott, J.C.; Arnesen, S.J. The refugee health information network: A source of multilingual and multicultural health information. J. Consum. Health Internet 2008, 12, 1-12. [CrossRef]

66. Blair, T.R.W. "Community ambassadors" for South Asian elder immigrants: Late-life acculturation and the roles of community health workers. Soc. Sci. Med. 2012, 75, 1769-1777. [CrossRef]

67. Cook, T.; Wills, J. Engaging with marginalized communities: The experiences of London health trainers. Perspect. Public Health 2011, 132, 221-227. [CrossRef]

68. Hesselink, A.E.; Verhoeff, A.P.; Stronks, K. Ethnic Health Care Advisors: A Good Strategy to Improve the Access to Health Care and Social Welfare Services for Ethnic Minorities? J. Community Health 2009, 34, 419-429. [CrossRef]

69. Pejic, V.; Hess, R.S.; Miller, G.E.; Wille, A. Family first: Community-based supports for refugees. Am. J. Orthopsychiatry 2016, 86, 409-414. [CrossRef] [PubMed] 
70. Shommu, N.S.; Ahmed, S.; Rumana, N.; Barron, G.R.S.; McBrien, K.A.; Turin, T.C. What is the scope of improving immigrant and ethnic minority healthcare using community navigators: A systematic scoping review. Int. J. Equity Health 2016, 15, 6. [CrossRef] [PubMed]

71. Verhagen, I.; Ros, W.J.; Steunenberg, B.; de Wit, N.J. Culturally sensitive care for elderly immigrants through ethnic community health workers: Design and development of a community based intervention programme in the Netherlands. BMC Public Health 2013, 13, 227. [CrossRef] [PubMed]

72. Verhagen, I.; Steunenberg, B.; de Wit, N.J.; Ros, W.J. Community health worker interventions to improve access to health care services for older adults from ethnic minorities: A systematic review. BMC Health Serv. Res. 2014, 14, 497. [CrossRef]

73. El Ansari, W.; Newbigging, K.; Roth, C.; Malik, F. The role of advocacy and interpretation services in the delivery of quality healthcare to diverse minority communities in London, United Kingdom. Health Soc. Care Community 2009, 17, 636-646. [CrossRef] [PubMed]

74. Yang, J.S.; Kagawa-Singer, M. Increasing access to care for cultural and linguistic minorities: Ethnicity-specific health care organizations and infrastructure. J. Health Care Poor Underserved 2007, 18, 532-549. [CrossRef]

75. Eggert, L.K.; Blood-Siegfried, J.; Champagne, M.; Al-Jumaily, M.; Biederman, D.J. Coalition Building for Health: A Community Garden Pilot Project with Apartment Dwelling Refugees. J. Community Health Nurs. 2015, 32, 141-150. [CrossRef]

76. Brown, N.J.; Barton, J.A. A collaborative effort between a state migrant health program and a baccalaureate nursing program. J. Community Health Nurs. 1992, 9, 151-159. [CrossRef]

77. Connor, A.; Rainer, L.P.; Simcox, J.B.; Thomisee, K. Increasing the delivery of health care services to migrant farm worker families through a community partnership model. Public Health Nurs. 2007, 24, 355-360. [CrossRef]

78. Goodkind, J.R.; Githinji, A.; Isakson, B. Reducing Health Disparities Experienced by Refugees Resettled in Urban Areas: A Community-Based Transdisciplinary Intervention Model. In Converging Disciplines; Kirst, M., Schaefer-McDaniel, N., Hwang, S., O'Campo, P., Eds.; Springer: New York, NY, USA, 2011. [CrossRef]

79. Levine, D.M.; Becker, D.M.; Bone, L.R.; Hill, M.N.; Tuggle, M.B.; Zeger, S.L. Community-academic health center partnerships for underserved minority populations. One Solut. A Natl. Crisis. JAMA 1994, 272, 309-311. [CrossRef]

80. Luque, J.S.; Castañeda, H. Delivery of mobile clinic services to migrant and seasonal farmworkers: A review of practice models for community-academic partnerships. J. Community Health 2013, 38, 397-407. [CrossRef] [PubMed]

81. Weissman, G.E.; Morris, R.J.; Ng, C.; Pozzessere, A.S.; Scott, K.C.; Altshuler, M.J. Global health at home: A student-run community health initiative for refugees. J. Health Care Poor Underserved 2012, 23, 942-948. [CrossRef] [PubMed]

82. Mason, D.M. Caring for the Unseen: Using Linking Social Capital to Improve Healthcare Access to Irregular Migrants in Spain. J. Nurs. Scholarsh. 2016, 48, 448-455. [CrossRef]

83. Miner, S.M.; Liebel, D.; Wilde, M.H.; Carroll, J.K.; Zicari, E.; Chalupa, S. Meeting the Needs of Older Adult Refugee Populations With Home Health Services. J. Transcult. Nurs. 2016, 28, 128-136. [CrossRef]

84. Afifi, R.A.; Makhoul, J.; El Hajj, T.; Nakkash, R.T. Developing a logic model for youth mental health: Participatory research with a refugee community in Beirut. Health Policy Plan. 2011, 26, 508-517. [CrossRef] [PubMed]

85. Priebe, S.; Sandhu, S.; Dias, S.F.; Gaddini, A.; Greacen, T.; Ioannidis, E.; Kluge, U.; Krasnik, A.; Lamkaddem, M.; Lorant, V.; et al. Good practice in health care for migrants: Views and experiences of care professionals in 16 European countries. BMC Public Health 2011, 11, 187. [CrossRef] [PubMed]

86. Aluko, Y. Carolinas Association for Community Health Equity-CACHE: A community coalition to address health disparities in racial and ethnic minorities in Mecklenburg County North Carolina. In Eliminating Healthcare Disparities in America; Williams, R.A., Williams, R.A., Eds.; Humana Press: Totowa, NJ, USA, 2007; pp. 365-374. [CrossRef]

87. Shaw-Taylor, Y. Culturally and linguistically appropriate health care for racial or ethnic minorities: Analysis of the US Office of Minority Health's recommended standards. Health Policy 2002, 62, 211-221. [CrossRef]

88. Mladovsky, P.; Ingleby, D.; McKee, M.; Rechel, B. Good practices in migrant health: The European experience. Clin. Med. 2012, 12, 248-252. [CrossRef] [PubMed] 
89. Tumiel-Berhalter, L.M.; Kahn, L.; Watkins, R.; Goehle, M.; Meyer, C. The implementation of Good For The Neighborhood: A participatory community health program model in four minority underserved communities. J. Community Health 2011, 36, 669-674. [CrossRef]

90. Gawde, N.C.; Sivakami, M.; Babu, B.V. Building Partnership to Improve Migrants' Access to Healthcare in Mumbai. Front. Public Health 2015, 3, 255. [CrossRef] [PubMed]

91. Flores, G. Devising, implementing, and evaluating interventions to eliminate health care disparities in minority children. Pediatrics 2009, 124, S214-S223. [CrossRef] [PubMed]

92. Pottie, K.; Hui, C.; Rahman, P.; Ingleby, D.; Akl, E.A.; Russell, G.; Ling, L.; Wickramage, K.; Mosca, D.; Brindis, C.D. Building Responsive Health Systems to Help Communities Affected by Migration: An International Delphi Consensus. Int. J. Environ. Res. Public Health 2017, 14, 144. [CrossRef] [PubMed]

93. Barenfeld, E.; Gustafsson, S.; Wallin, L.; Dahlin-Ivanoff, S. Understanding the "black box" of a health-promotion program: Keys to enable health among older persons aging in the context of migration. Int. J. Qual. Stud. Health Well-Being 2015, 10, 29013. [CrossRef] [PubMed]

94. Devillé, W.; Greacen, T.; Bogić, M.; Dauvrin, M.; Dias, S.F.; Gaddini, A.; Jensen, N.K.; Karamanidou, C.; Kluge, U.; Mertaniemi, R.; et al. Health care for immigrants in Europe: Is there still consensus among country experts about principles of good practice? A Delphi study. BMC Public Health 2011, 11, 699. [CrossRef] [PubMed]

95. Barenfeld, E.; Gustafsson, S.; Wallin, L.; Dahlin-Ivanoff, S. Supporting decision-making by a health promotion programme: Experiences of persons ageing in the context of migration. Int. J. Qual. Stud. Health Well-Being 2017, 12, 1337459. [CrossRef] [PubMed]

96. Ferrera, M.J. Integrating Principles of Positive Minority Youth Development with Health Promotion to Empower the Immigrant Community: A Case Study in Chicago. J. Community Pract. 2017, 25, 504-523. [CrossRef]

97. De Paoli, L. Access to health services for the refugee community in Greece: Lessons learned. Public Health 2018, 157, 104-106. [CrossRef]

98. Department of Health and Human Services. Refugee and Asylum Seeker Health Services- Guidelines for the Community Health Program. 2015. Available online: https://refugeehealthnetwork.org.au/refugee-andasylum-seeker-health-services-guidelines-for-the-community-health-program (accessed on 14 February 2020).

99. Philis-Tsimikas, A.; Gallo, L.C. Implementing Community-Based Diabetes Programs: The Scripps Whittier Diabetes Institute Experience. Curr. Diabetes Rep. 2014, 14, 462. [CrossRef]

100. Ornelas, I.J.; Ho, K.; Jackson, J.C.; Moo-Young, J.; Le, A.; Do, H.H.; Lor, B.; Magarati, M.; Zhang, Y.; Taylor, V.M. Results From a Pilot Video Intervention to Increase Cervical Cancer Screening in Refugee Women. Health Educ. Behav. Off. Publ. Soc. Public Health Educ. 2018, 45, 559-568. [CrossRef]

101. Ahmad, F.; Jandu, B.; Albagli, A.; Angus, J.E.; Ginsburg, O. Exploring ways to overcome barriers to mammography uptake and retention among South Asian immigrant women. Health Soc. Care Community 2013, 21, 88-97. [CrossRef]

102. Choi, J. Development and pilot test of pictograph-enhanced breast health-care instructions for community-residing immigrant women. Int. J. Nurs. Pract. 2012, 18, 373-378. [CrossRef] [PubMed]

103. Escribà-Agüir, V.; Rodríguez-Gómez, M.; Ruiz-Pérez, I. Effectiveness of patient-targeted interventions to promote cancer screening among ethnic minorities: A systematic review. Cancer Epidemiol. 2016, 44, 22-39. [CrossRef] [PubMed]

104. Shirazi, M.; Shirazi, A.; Bloom, J. Developing a culturally competent faith-based framework to promote breast cancer screening among Afghan immigrant women. J. Relig. Health 2015, 54, 153-159. [CrossRef] [PubMed]

105. Alzubaidi, H.; Mc Namara, K.; Browning, C. Time to question diabetes self-management support for Arabic-speaking migrants: Exploring a new model of care. Diabet. Med. A J. Br. Diabet. Assoc. 2017, 34, 348-355. [CrossRef]

106. Lew, K.N.; Mclean, Y.; Byers, S.; Taylor, H.; Braizat, O.M. Combined Diabetes Prevention and Disease Self-Management Intervention for Nicaraguan Ethnic Minorities: A Pilot Study. Prog. Community Health Partnersh. Res. Educ. Action 2017, 11, 357-366. [CrossRef] [PubMed] 
107. Wieland, M.L.; Njeru, J.W.; Hanza, M.M.; Boehm, D.; Singh, D.; Yawn, B.P.; Patten, C.A.; Clark, M.M.; Weis, J.A.; Osman, A.; et al. Stories for change: Pilot feasibility project of a diabetes digital storytelling intervention for refugee and immigrant adults with type 2 diabetes. J. Gen. Intern. Med. 2017, 32, S319.

108. Zeh, P.; Sandhu,H.K.; Cannaby, A.M.; Sturt, J.A. The impact of culturally competent diabetes care interventions for improving diabetes-related outcomes in ethnic minority groups: A systematic review. Diabet. Med. A J. Br. Diabet. Assoc. 2012, 29, 1237-1252. [CrossRef]

109. Bader, A.; Musshauser, D.; Sahin, F.; Bezirkan, H.; Hochleitner, M. The Mosque Campaign: A cardiovascular prevention program for female Turkish immigrants. Wien. Klin. Wochenschr. 2006, 118, 217-223. [CrossRef]

110. Van De Vijver, S.; Oti, S.O.; Van Charante, E.P.M.; Allender, S.; Foster, C.; Lange, J.; Oldenburg, B.; Kyobutungi, C.; Agyemang, C. Cardiovascular prevention model from Kenyan slums to migrants in the Netherlands. Glob. Health 2015, 11, 11. [CrossRef]

111. Sethi, S.; Jonsson, R.; Skaff, R.; Tyler, F. Community-Based Noncommunicable Disease Care for Syrian Refugees in Lebanon. Glob. Health Sci. Pract. 2017, 5, 495-506. [CrossRef]

112. Siddaiah, R.; Roberts, J.E.; Graham, L.; Little, A.; Feuerman, M.; Cataletto, M.B. Community health screenings can complement public health outreach to minority immigrant communities. Prog. Community Health Partnersh. Res. Educ. Action 2014, 8, 433-439. [CrossRef] [PubMed]

113. Cheng, I.-H.; Wahidi, S.; Vasi, S.; Samuel, S. Importance of community engagement in primary health care: The case of Afghan refugees. Aust. J. Prim. Health 2015, 21, 262-267. [CrossRef] [PubMed]

114. Levin-Zamir, D.; Keret, S.; Yaakovson, O.; Lev, B.; Kay, C.; Verber, G.; Lieberman, N. Refuah Shlema: A cross-cultural programme for promoting communication and health among Ethiopian immigrants in the primary health care setting in Israel: Evidence and lessons learned from over a decade of implementation. Glob. Health Promot. 2011, 18, 51-54. [CrossRef]

115. Feldman, R. Primary health care for refugees and asylum seekers: A review of the literature and a framework for services. Public Health 2006, 120, 809-816. [CrossRef] [PubMed]

116. McMurray, J.; Breward, K.; Breward, M.; Alder, R.; Arya, N. Integrated primary care improves access to healthcare for newly arrived refugees in Canada. J. Immigr. Minority Health 2014, 16, 576-585. [CrossRef] [PubMed]

117. Phillips, C.; Hall, S.; Elmitt, N.; Bookallil, M.; Douglas, K. People-centred integration in a refugee primary care service: A complex adaptive systems perspective. J. Ournal Integr. Care 2017, 25, 26-38. [CrossRef]

118. Pottie, K.; Batista, R.; Mayhew, M.; Mota, L.; Grant, K. Improving delivery of primary care for vulnerable migrants: Delphi consensus to prioritize innovative practice strategies. Can. Fam. Physician 2014, 60, e32-e40.

119. Griswold, K.S.; Pottie, K.; Kim, I.; Kim, W.; Lin, L. Strengthening effective preventive services for refugee populations: Toward communities of solution. Public Health Rev. 2018, 39, 3. [CrossRef]

120. McElmurry, B.J.; Park, C.G.; Buseh, A.G. The nurse-community health advocate team for urban immigrant primary health care. J. Nurs. Scholarsh. Off. Publ. Sigma Theta Tau Int. Honor Soc. Nurs. 2003, 35, $275-281$. [CrossRef]

121. Kim, M.J.; Cho, H.-I.; Cheon-Klessig, Y.S.; Gerace, L.M.; Camilleri, D.D. Primary health care for Korean immigrants: Sustaining a culturally sensitive model. Public Health Nurs. 2002, 19, 191-200. [CrossRef]

122. Yelland, J.; Riggs, E.; Szwarc, J.; Casey, S.; Dawson, W.; Vanpraag, D.; East, C.; Wallace, E.; Teale, G.; Harrison, B.; et al. Bridging the Gap: Using an interrupted time series design to evaluate systems reform addressing refugee maternal and child health inequalities. Implement. Sci. 2015, 10, 62. [CrossRef] [PubMed]

123. Hutchins, V.; Walch, C. Meeting minority health needs through special MCH projects. Public Health Rep. 1989, 104, 621-626. [PubMed]

124. Bhagat, R.; Johnson, J.; Grewal, S.; Pandher, P.; Quong, E.; Triolet, K. Mobilizing the community to address the prenatal health needs of Immigrant Punjabi women. Public Health Nurs. 2002, 19, 209-214. [CrossRef] [PubMed]

125. Jackson, S.; Camacho, D.; Freund, K.M.; Bigby, J.; Walcott-McQuigg, J.; Hughes, E.; Nunez, A.; Dillard, W.; Weiner, C.; Weitz, T.; et al. Women's health centers and minority women: Addressing barriers to care. The National Centers of Excellence in Women's Health. J. Women's Health Gend. Based Med. 2001, 10, 551-559. [CrossRef] [PubMed]

126. Sheikh, M.; MacIntyre, C.R. The impact of intensive health promotion to a targeted refugee population on utilisation of a new refugee paediatric clinic at the children's hospital at Westmead. Ethn. Health 2009, 14, 393-405. [CrossRef] 
127. Reavy, K.; Hobbs, J.; Hereford, M.; Crosby, K. A new clinic model for refugee health care: Adaptation of cultural safety. Rural Remote Health 2012, 12, 1826.

128. Krause, S.; Williams, H.A.; Onyango, M.A.; Sami, S.; Doedens, W.; Giga, N.; Stone, E.; Tomczyk, B. Reproductive health services for Syrian refugees in Zaatri Camp and Irbid City, Hashemite Kingdom of Jordan: An evaluation of the Minimum Initial Services Package. Confl. Health 2015, 9, S4. [CrossRef]

129. Transforming our world: The 2030 Agenda for Sustainable Development. Available online: http://www.un. org/ga/search/view_doc.asp?symbol=A/RES/70/1\&Lang=E (accessed on 15 April 2020).

(C) 2020 by the authors. Licensee MDPI, Basel, Switzerland. This article is an open access article distributed under the terms and conditions of the Creative Commons Attribution (CC BY) license (http://creativecommons.org/licenses/by/4.0/). 